\title{
Induction of the oviposition in bearded dragon (Pogona vitticeps) with postovulatory egg retention (dystocia) - a case report
}

\section{Maša Efendić́ ${ }^{1}$, Marko Samardžija ${ }^{2 *}$, Hrvoje Capak ${ }^{3}$, Goran Bačić Ivona Žura Žaja ${ }^{4}$, Vladimir Magaš ${ }^{5}$, and Nino Maćešić ${ }^{2}$}

\author{
${ }^{I}$ Faculty of Veterinary Medicine, University of Zagreb, Zagreb, Croatia, $\mathrm{PhD}$ \\ ${ }^{2}$ Clinic for Obstetrics and Reproduction, Faculty of Veterinary Medicine, University of Zagreb, \\ Zagreb, Croatia \\ ${ }^{3}$ Department of Radiology, Ultrasound Diagnostic and Physical Therapy, Faculty of Veterinary Medicine, \\ University of Zagreb, Zagreb, Croatia \\ ${ }^{4}$ Department of Physiology and Radiobiology, Faculty of Veterinary Medicine, University of Zagreb, Zagreb, Croatia \\ ${ }^{5}$ Department for Reproduction, Fertility and Artificial Insemination, Faculty of Veterinary Medicine, \\ University of Belgrade, Belgrade, Serbia
}

EFENDIĆ, M., M. SAMARDŽIJA, H. CAPAK, G. BAČIĆ, I. ŽURA ŽAJA, V. MAGAŠ, N. MAĆEŚSIĆ: Induction of the oviposition in bearded dragon (Pogona vitticeps) with postovulatory egg retention (dystocia) - a case report. Vet. arhiv 89, 131-142, 2019.

ABSTRACT

A 2-year-old bearded dragon (Pogona vitticeps), was admitted to the Clinic due to interrupted oviposition. The lizard had laid 1 egg with an insufficiently calcified eggshell 4 days before admission. The lizard was lethargic, without appetite and had been digging the substrate inside the terrarium. During the clinical examination, hard consistency formations were palpable in the coelom. Ultrasound and X-ray findings confirmed the presence of 14 calcified eggs in the coelom cavity. The diagnosis suggested postovulatory dystocia. Therapy included rehydration of the patient and induction of oviposition. Two doses of calcium borogluconate were administrated $\mathrm{i} / \mathrm{m}(35 \mathrm{mg} / \mathrm{kg}$ and $50 \mathrm{mg} / \mathrm{kg}$ after 30 minutes) and oxytocin (5 IU) was also given intramuscularly. Within the next 20 hours the patient laid 14 calcified eggs. On X-ray follow up 24 hours after therapy, no retained eggs were observed so the animal was released from the Clinic. The owners were advised that the current diet should be supplemented with calcium and phosphorus in the prescribed daily dose, to prevent future dystocia. On the next oviposition the animal successfully laid 38 calcified eggs. This case report describes the clinical presentation and diagnosis of dystocia and a therapeutic protocol for induction of oviposition in a bearded dragon. The described hormonal protocol is important due to the fact that the oxytocin causes induction of the oviposition more than 72 hours from commencing the oviposition which is different from the findings of other authors who reported that its effect only lasts up to 72 hours.

Key words: non-obstructive dystocia; retained eggs; lizard; oxytocin; therapy

*Corresponding author:

Marko Samardžija, DVM, MSc, PhD, Full Professor, Clinic for Obstetrics and Reproduction, Faculty of Veterinary Medicine, University of Zagreb, Heinzelova 55, 10000 Zagreb, Croatia, Phone: +385 12390 321; Fax: +385 12441 390; E-mail: smarko@vef.hr 
M. Efendić et al.: Induction of the oviposition in bearded dragon with postovulatory egg retention

\section{Introduction}

A 2-year-old bearded dragon (Pogona vitticeps), weighing $300 \mathrm{~g}$, in good general condition, was admitted to the Clinic for Obstetrics and Reproduction at the Faculty of Veterinary Medicine in Zagreb due to interrupted oviposition. Four days before admission, the lizard had laid one egg with an insufficiently calcified eggshell in her own terrarium. She had not had any previous ovipositions. Since then, the lizard had been lethargic, had loss of appetite and had been digging holes in the substrate inside the terrarium. The owners did not notice any other changes in her behavior or discharge from the cloaca.

The animal had been kept in adequate conditions. The lizard lives alone in a terrarium $90 \mathrm{~cm} \times 60 \mathrm{~cm} \times 35 \mathrm{~cm}$, at a maintained temperature of $30^{\circ} \mathrm{C}$ around a spotlight while under the spotlight the temperature is $42^{\circ} \mathrm{C}$ measured by an IR Laser Temp gun infrared digital thermometer. In the coldest part of the terrarium, the temperature is $29{ }^{\circ} \mathrm{C}$ and humidity is $50 \%$ measured by a digital thermo-hygrometer.

The lightening is suitable for the animal species: 8\% UV-B lightening (JBL, T-8, 90 $\mathrm{cm}$ ) set on $30 \mathrm{~cm}$ above the substrate. For heating a JBL Reptile Day, $50 \mathrm{~W}$ spotlight is used, with $1 \%$ UV-A. The lightening bulbs were 5 months old and the owner replaces them every 8 months. The terrarium is filled with substrate $(100 \%$ Lolo terra natura terrarium sand) and the cave in the terrarium is filled with sufficient substrate (sand) where the thickness is always around $20 \mathrm{~cm}$.

The daily diet is based on the insects (grasshoppers Locusta migratoria, cockroaches Blaptica dubia and Blatta lateralis, crickets Gryllus campestris, superworms Zoophobas morio), vegetables (carrot, zucchini and radicchio), fruit (apples and pears) and occasionally insectivore gel premix ("grub pie", Repashy superfoods).

While collecting anamnestic data it was determined that the owners did not add calcium and phosphorus supplement to the diet, which stood out as a possible cause of the unsuccessful oviposition.

A clinical exam was performed. The animal was mildly dehydrated as seen from the skin test (the skin stayed in tented position for $1 \mathrm{sec}$, but animal did not have sunken eyes or wrinkled skin). On the ventral side of the distended coelom hard consistency formations were palpable, which coincided with retained eggs in the reproductive tract. The lizard did not show signs of pain during palpation. The patient was tachypneic.

Blood chemistry and complete blood count were unremarkable. X-ray and ultrasound diagnostics were performed immediately after the clinical exam. On the dorso-ventral radiograph projection of the caudal region of the coelom cavity, 14 well-defined calcified eggs were visible (Fig. 1). Ultrasound findings of the coelom cavity confirmed the presence of calcified eggs. There was no presence of free fluid in the coelom, and no egg- 
shell fragments in the reproductive tract and the eggs were well calcified. The diagnosis was suggested of non-obstructive postovulatory dystocia.

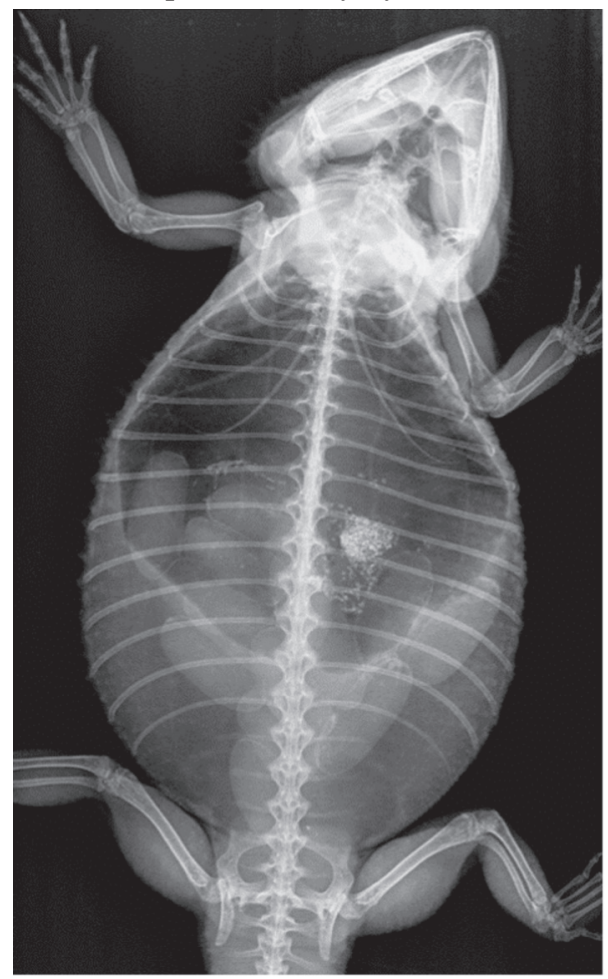

Fig. 1 Total body dorso-ventral radiograph of the bearded dragon (Pogona vitticeps) show 14 well-defined, rounded mineralized shadows in the caudal part of the coelom cavity. There was no presentation of free fluid in the coelom. Shell calcification suggests postovulatory egg retention.

After the X-ray and ultrasound diagnostic procedures, the therapeutic protocol included rehydration, stabilization of the patient and induction of ovipiosition of the retained eggs.

The patient was hospitalized and first rehydrated with a warm depot injection $(\mathrm{s} / \mathrm{c})$ of isotonic solution ringer lactate (R-L, Fresenius kabi, Germany) $+5 \%$ glucose (Fresenius kabi, Germany) at $2 \%$ body weight. Calcium borogluconate (Calcii borogluconas $40 \%$, Genera, Croatia) at a dose of $35 \mathrm{mg} / \mathrm{kg}$ was administered i $/ \mathrm{m}$. After 30 minutes, a second dose of Ca-borogluconate $(50 \mathrm{mg} / \mathrm{kg} \mathrm{i} / \mathrm{m})$ was administered and $5 \mathrm{IU} / \mathrm{kg}$ of oxytocin (Genera, Croatia) was given i/m. 
M. Efendić et al.: Induction of the oviposition in bearded dragon with postovulatory egg retention

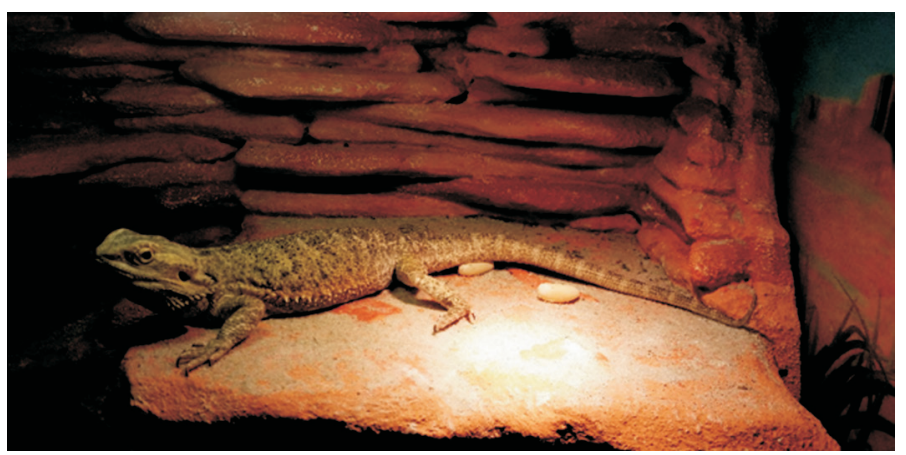

Fig. 2. Bearded dragon 20 hours after the therapeutic protocol started oviposition in the terrarium of well-calcified eggs.

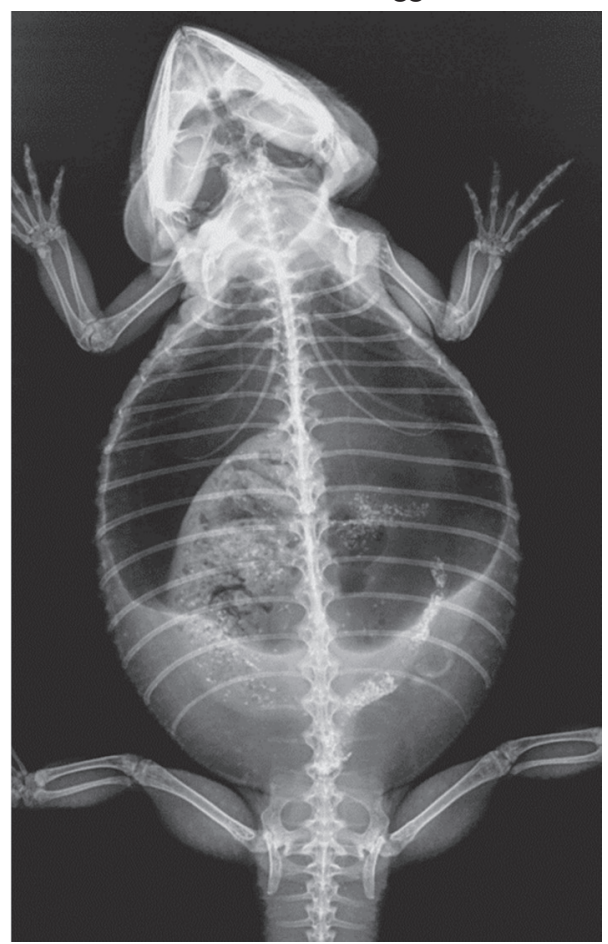

Fig. 3. Total body radiograph 24 hours after therapy and oviposition. There is a huge amount of ingesta in the gastrintestinal tract, but there is no presentation of retained eggs or free fluid in the coelom cavity. 
The animal was put in the terrarium measuring $60 \mathrm{~cm} \times 50 \mathrm{~cm} \times 30 \mathrm{~cm}$, with a deep substrate layer (Lolo terra natura bedding vermiculite), at an adequate temperature (30 ${ }^{\circ} \mathrm{C}$ ) and $55 \%$ humidity to proceed with oviposition. Lightening in terrarium was UVB $10 \%$ (exo terra, T-8, $60 \mathrm{~cm}$, set $30 \mathrm{~cm}$ high from substrate) and the heating spotlight was a Daytime heat lamp (Zoomed, $40 \mathrm{~W}$ ). Every two hours the bearded dragon was placed in a warm bath for 2-3 minutes to stimulate oviduct contractions. Within the next 20 hours the patient was monitored, and laid 14 calcified eggs (Fig. 2).

Since after 20 hours the animal calmed down, stopped digging the substrate in the terrarium, and her appetite was reestablished, a control X-ray was performed 24 hours after therapy. No presence of retained eggs or free fluid in the coelom cavity were observed (Fig. 3), therefore the lizard was discharged from the Clinic.

The owners were advised that the current diet should be supplemented with calcium in the prescribed daily dose, to prevent future dystocia. The next oviposition was after 13 months where the animal successfully laid 38 well-formed calcified eggs. The eggs unfortunately were not fertilized since the bearded dragon lives without the presence of a male.

\section{Discussion}

Preovulatory stasis and postovulatory egg retention have been reported previously in bearded dragons (MELIDONE et al., 2008; WRIGHT et al., 2008). Postovulatory egg retention, also known as egg binding (dystocia) is one of the most common reproductive disorders of captive female lizards (EFENDIĆ et al., 2017). Causes of dystocia may be of obstructive or non-obstructive etiology, resulting in difficulties or complete inability to lay eggs (oviposition). A large number of eggs or insufficient calcification of the egg shell and metabolic bone disease are the most common causes of egg retention in reptiles (INNIS and BOYER, 2002; McARTHUR, 2004b; JOHN and SYKES, 2010). Also, inappropriate husbandry and inadequate nutrition may lead to reproductive disorders (RENDELE and CRACKNELL, 2012; EFENDIĆ et al., 2017).

Other authors (MELIDONE et al., 2008; WRIGHT et al., 2008) have reported clinical signs such as depression, lethargy, anorexia, dyspnea, constipation and lack of perception and proprioception in cases of dystocia.

Ultrasonography and X-ray diagnostics are the first non-invasive choice of diagnostic procedure, therefore in our case we proceeded with them after the clinical exam.

As GUMPERBERGER (2017) reported, a follow-up radiograph helps to ensure that no shell fragments have remained in the salpinx. Radiographic findings in lizards with dystocia indicate the specific egg-shell formation (well-rounded) and the loss of egg contents. The same author mentioned that X-ray is also helpful in detecting secondary causes of dystocia, such as pelvic fracture or constipation. 
M. Efendić et al.: Induction of the oviposition in bearded dragon with postovulatory egg retention

During the X-ray diagnostics we are able to estimate the number and position of retained eggs and the stage of egg shell calcification (EFENDIĆ et al., 2017).

Using ultrasonography, a distinction between preovulatory stasis and dystocia, can be made based on an estimation of egg shell calcification (STAHL, 2006). SILVERMAN (2006) recommends a linear ultrasound probe (7-15 MHz) and BUCY et al. (2015) microconvex ultrasound probes (5-8 MHz) to be used on Pogona vitticeps.

With X-ray and ultrasound, it is possible to observe the presence of free fluid in the coelom cavity. Therefore, we performed X-ray and ultrasound in our patient to make a definite diagnosis of dystocia.

Many authors (McARTHUR, 2001; JOHN and SYKES, 2010; CARPENTER, 2013; RIVERA and FLEMING, 2013; EFENDIĆ et al., 2017) suggested that blood parameters should be determined in order to assess the clinical status of the patient, and in our case, due to the unremarkable results of hematology and biochemistry, the patient was found to be in a good clinical condition.

With this patient, there were only two therapeutic options for non-obstructive dystocia: hormonally inducing the oviposition or a surgical procedure. Before these options, first the patient should be stabilized and rehydrated, and then we need to estimate the clinical status of the patient. For rehydration of lizards, MELIDONE et al. (2008) suggested ringer-lactate in the form of a depot injection $(\mathrm{s} / \mathrm{c})(15-30 \mathrm{~mL} / \mathrm{kg})$ into which $5 \%$ dextrose is diluted in a dosage of $3.3 \mathrm{~mL} / \mathrm{kg}$. Hypertonic solutions such as $5 \%$ dextrose $(252 \mathrm{mOsm} / \mathrm{L})$ with a $\mathrm{pH}$ of 4.3 can be used in reptiles. They can tolerate severe dehydration and extensive plasma osmolality (e.g. 250-400 mOsm/L) as well as electrolyte concentrations (GIBBONS, 2009). If 5\% dextrose is not available on the market, other fluid types, such as 5\% glucose (Glucosum monohydricum, $277 \mathrm{mOsm} / \mathrm{L}$ ), can be used (EFENDIĆ et al., 2017).

In our case, after rehydration, the patient was stabilized, so we could proceed with the hormonal protocol of induction of oviposition to avoid a surgical procedure. If the animal had had obstructive dystocia, surgery would have been the only choice to save the animal's life.

The aim of the hormonal protocol is to stimulate contraction of the fallopian tube by application of Calcium gluconate and the hormone oxytocin. As said before, some authors (GREEK, 2010; RIVERA and FLEMING, 2013) recommended that calcium is applied before the oxytocin, therefore our therapy protocol started with calcium borogluconate and continued with a single dose of oxytocin. RIVERA and FLEMING (2013) reported a dose of calcium gluconate of $100 \mathrm{mg} / \mathrm{kg}$, while others (INNIS and BOYER, 2002; McARTHUR, 2004a; JOHN and SYKES, 2010) reported a dose of 50-100 mg/kg. The dosage of calcium gluconate has to be estimated according to the degree of calcification 
of the egg shell (JOHNSON, 2006). If the calcium dose is repeated during the therapeutic protocol, a total dosage of $100 \mathrm{mg} / \mathrm{kg}$ should not be exceeded (EFENDIĆ et al., 2017).

The range for single dose application of the oxytocin in lizards is from $3 \mathrm{IU} / \mathrm{kg}$ to $30 \mathrm{IU} / \mathrm{kg}$ (INNIS and BOYER, 2002; McARTHUR, 2004c; JOHNSON, 2006; FELDMAN, 2007; TUCKER et al., 2007; GREEK, 2010; JOHN and SYKES, 2010), so the average dose is 3-15 IU/kg (EFENDIĆ et al. 2017), and should be determined according to the patient's clinical status and diagnostic findings. PERRY (2014) pointed out that, in the case of non-obstructive dystocia in lizards, oxytocin is only effective when given in the first $72 \mathrm{~h}$ from the time the symptoms of oviposition occur.

The recommendation is that calcium is applied approximately one hour before the oxytocin (GREEK, 2010; RIVERA and FLEMING, 2013). Several authors (McARTHUR, 2004a; DENARDO, 2006; JOHN and SYKES, 2010; PERRY, 2014) pointed out that oxytocin can be administered two or three times every 20-60 min. After the third oxytocin application, if there is no progression, hormonal therapy must be stopped and surgery should be performed under general anesthesia.

With the above mentioned protocol, in some cases the authors (GREEK, 2010; EFENDIĆ et al., 2017) suggested giving the lizard a warm bath to stimulate oviduct contractions, as we did in our case. Within $24 \mathrm{~h}$ after the last dose of oxytocin, control $\mathrm{X}$-ray should be performed to determine if the therapeutic protocol has been successful.

\section{Conclusions}

A detailed anamnesis, proper diagnostic imaging, and estimation of the clinical status of the patient are important to make the correct diagnosis of dystocia in bearded dragons and to choose the appropriate therapeutic protocol.

If the owners do not want to use the animal for further reproduction, the best choice is surgical therapy (ovariosalpingectomy). Adequate microclimatic conditions as well as good quality and appropriate nutrition of bearded dragons should be achieved, in order to prevent reproductive disorders.

Our patient was induced using the above mentioned ranges of calcium borogluconate and oxytocin, 85-90 hours after the first symptoms of oviposition occurred, which told us that the effect of oxytocin stimulation of oviposition lasts more than 72 hours. Since our patient went through successful oviposition 20 hours after therapy, we may conclude that the described hormonal protocol is an appropriate choice for therapy for non-obstructive dystocia in bearded dragons with good clinical status. 
M. Efendić et al.: Induction of the oviposition in bearded dragon with postovulatory egg retention

\section{References}

BUCY, D. S., D. S. GUZMAN, A. L. ZWINGENBERGER (2015): Ultrasonographic anatomy of bearded dragons (Pogona vitticeps). J. Am. Vet. Med. Assoc. 246, 868-876.

DOI: $10.2460 /$ javma.246.8.868

CARPENTER, J. W. (2013): Reptiles. In: Exotic Animal Formulary (Marion, C. J., Ed.), Elsevier Inc, St. Louis, MO, p. 109.

DENARDO, D. (2006): Dystocias. In: Reptile Medicine and Surgery (Mader, D., Ed.), Elsevier Inc, St. Louis, MO, pp. 787-792.

DOI: 10.1016/B0-72-169327-X/50057-2

EFENDIĆ, M., M. SAMARDŽIJA, N. PRVANOVIĆ BABIĆ, G. BAČIĆ, T. KARADJOLE, M. LOJKIĆ, H. CAPAK, N. MAĆEŠIĆ (2017): Postovulatory egg retention (Dystocia) in lizards - diagnostic and therapeutic options. Kleintierpraxis 62, 754-764.

FELDMAN, M. L. (2007): Some options to induce oviposition in turtles. Chelonian Conserv. Bi. 6, 313-320.

DOI: 10.2744/1071-8443(2007)6[313:SOTIOI]2.0.CO;2

GIBBONS, P. M. (2009): Critical care nutrition and fluid therapy in reptiles. Proceedings of the $15^{\text {th }}$ Annual International Veterinary Emergency \& Critical Care Symposium, 9-13 ${ }^{\text {th }}$ September, Chicago, Illinois, pp. 91-94.

GREEK, T. (2010): Dystocia in reptiles. Proceedings of the North American Veterinary Conference, Small animal and exotics, 16-20 January, Orlando, Florida, pp. 1674-1675.

GUMPENBERGER, M. (2017): Diagnostic imaging of reproductive tract disorders in reptiles. Vet. Clin. Exot. Anim. 20, 327-343.

DOI: $10.1016 /$ j.cvex.2016.11.003

INNIS, C., T. H. BOYER (2002): Chelonian reproductive disorders. Vet. Clin. North Am. Exot. Anim. Pract. 5, 555-578.

DOI: 10.1016/S1094-9194(02)00013-0

JOHN, M., I. V. SYKES (2010): Updates and practical approaches to reproductive disorders in reptiles. Vet. Clin. North Am. Exot. Anim. Pract. 13, 349-373.

DOI: $10.1016 /$ j.cvex.2010.05.013

JOHNSON, R. (2006): Dystocia in an injured common eastern long-necked turtle (Chelodina longicollis). Vet. Clin. North Am. Exot. Anim. Pract. 9, 575-581.

DOI: $10.1016 /$ j.cvex.2006.05.010

McARTHUR, S. (2001): Folicular stasis in captive chelonian, Testudo spp. Proceedings of the Association of Reptilian and Amphibian Veterinarians, $8^{\text {th }}$ Annual Conference, 19-23 September, Orlando, Florida, pp. 75-86.

McARTHUR, S. (2004a): Dystocia. In: Medicine and Surgery of Tortoises and Turtles. (McArthur, S., R. Wilkinson, J. Meyer, Eds.), Blackwell Publishing, Oxford, UK, pp. 316-318. 
M. Efendić et al.: Induction of the oviposition in bearded dragon with postovulatory egg retention

McARTHUR, S. (2004b): Interpretation of presenting signs. In: Medicine and Surgery of Tortoises and Turtles (McArthur, S., R. Wilkinson, J. Meyer, Eds.), Blackwell Publishing, Oxford, UK, pp. 273-280.

DOI: $10.1002 / 9780470698877 . c h 11$

McARTHUR, S. (2004c): Reproductive system. In: Medicine and Surgery of Tortoises and Turtles (McArthur, S., R. Wilkinson, J. Meyer, Eds.), Blackwell Publishing, Oxford, UK, pp. 57-63.

MELIDONE, R., J. S. KNOLL, N. PARRY (2008): Preovulatory stasis and dystocia in oviparous lizards. Vet. Med.-US 103, 595-598.

PERRY, S. M. (2014): Therapeutic Review: Oxytocin. J. Exot. Pet. Med. 23, 294-300.

DOI: $10.1053 /$ j.jepm.2014.06.013

RENDLE, M., J. CRACKNELL (2012): Reptiles: biology and husbandry. In: BSAVA Manual of Exotic Pet and Wildlife Nursing (Varga, M., R. Lumbis, L. Gott, Eds.), BSAVA, Gloucester, UK, pp. 96-99.

DOI: $10.22233 / 9781910443132.4$

RIVERA, S., G. FLEMING (2013): To breed or not to breed; reproductive tract disease of reptiles. Proceedings of the North American Veterinary Conference, Small Animal and Exotics, 19-23 January, Orlando, Florida.

SILVERMAN, S. (2006): Diagnostic imaging. In: Reptile Medicine and Surgery (Mader, D., Ed.), Elsevier Inc, St. Louis, MO, pp. 481-482.

DOI: 10.1016/B0-72-169327-X/50033-X

STAHL, S. J. (2006): Reptile Obstetrics. Proceedings of the North American Veterinary Conference, Small animal and exotics, 7-11 January, Orlando, Florida.

TUCKER, J. K., D. L. THOMAS, J. ROSE (2007): Oxytocine dosage in turtles. Chelonian Conserv. Bi. 6, 321-234.

DOI: 10.2744/1071-8443(2007)6[321:ODIT]2.0.CO;2

WRIGHT, K. (2008): Two common disorders of captive bearded dragons (Pogona vitticeps): nutritional secondary hyperparathyroidism and constipation. J. Exot. Pet. Med. 43, 267-272.

DOI: $10.1053 /$ j.jepm.2008.07.004

Received: 22 March 2018

Accepted: 19 June 2018

EFENDIĆ, M., M. SAMARDŽIJA, H. CAPAK, G. BAČIĆ, I. ŽURA ŽAJA, V. MAGAŠ, N. MAĆEŠ́ IĆ: Indukcija ovipozicije u bradate agame (Pogona vitticeps) s postoovulacijskom retencijom jaja (distocija) - prikaz slučaja. Vet. arhiv 89, 131$142,2019$.

\section{SAŽETAK}

Bradata agama (Pogona vitticeps) u dobi od dvije godine zaprimljena je na kliniku zbog prekida ovipozicije. Gušterica je četiri dana prije dolaska na kliniku izbacila jedno djelomično kalcificirano jaje. Otada je apatična, nema apetita te učestalo kopa supstrat u terariju. Tijekom kliničkog pregleda palpacijom celoma 
M. Efendić et al.: Induction of the oviposition in bearded dragon with postovulatory egg retention

pronađene su tvorbe tvrde konzistencije. Ultrazvučni i rendgenski nalaz potvrdio je prisutnost 14 kalcificiranih jaja u celomnoj šupljini što upućuje na postovulacijsku distociju. Terapija je uključivala rehidraciju pacijenta i indukciju ovipozicije, stoga su aplicirane dvije doze kalcijeva boroglukonata $(35 \mathrm{mg} / \mathrm{kg}$ te nakon 30 minuta 50 $\mathrm{mg} / \mathrm{kg} \mathrm{im}$.) i oksitocin (5 i. j. im.). U sljedećih 20 sati gušterica je izbacila 14 kalcificiranih jaja. Na kontrolnom rendgenogramu 24 sata nakon terapije nije bilo vidljivih zaostalih jaja. Vlasnicima je savjetovano da trenutačnoj prehrani nadodaju kalcij i fosfor u propisanoj dnevnoj dozi kako bi se spriječila opetovana distocija. Prilikom sljedeće ovipozicije životinja je uspješno izbacila 38 kalcificiranih jaja. Ovaj prikaz slučaja opisuje klinički tijek i dijagnostiku distocije te terapijski protokol za indukciju ovipozicije u bradate agame. Opisan hormonski protokol važan je jer dokazuje da je učinak oksitocina na indukciju ovipozicije dulji od 72 sata što se razlikuje od navoda drugih autora koji tvrde da učinak traje do 72 sata od početka ovipozicije.

Ključne riječi: neopstruktivna distocija; zaostala jaja; gušter; oksitocin; terapija 